\section{Fraser B. Gurd (1883-1948)}

\author{
Joseph Schmoker, MD
}

Fraser Baillie Gurd (Figure 1), born in Montreal on January 6, 1883, was the 23rd president of the American Association for Thoracic Surgery, serving from 1940 to $1941 .{ }^{1}$ Gurd's paternal grandparents, Joseph and Marianne, immigrated to Canada from Ireland in 1847 with their 4 young children to escape a stagnant economy and the starvation caused by the potato famine. The trip was arduous for the malnourished travelers and within 6 weeks 3 of the 4 children were dead. The toll became evident in Gurd's grandfather Joseph, who was said to have been "lost to the drink," but who prudently brought what was left of his small family by river steamer to Montreal, setting up their household only a few blocks from the McGill Medical School and foreshadowing the future of several generations of Gurds.

Gurd's father David was 1 of 3 children born to the family after settling in Montreal. David's brother Charles, the lone surviving child from the overseas journey, hoped to become a physician but was forced to leave school early to help with the family finances. David, a promising young student in his own right, also had to quit school and at age 13 years went to work to help support the family after Joseph abandoned them. David took a position as an apprentice in the medical school and was assigned various odd jobs, but soon became fascinated with pharmacy. After reaching a mandatory educable age, he enrolled in a pharmacologic sciences tutorial program during his off-work hours and passed his pharmacy boards in 1871 . This was followed by matriculation at the McGill Medical School where William Osler became his instructor. After finishing his medical training in 1879, David set up his office from his new home in the tenement section of Grittentown, and soon had a thriving practice. He married Mary Ann Baillie in 1882 and they began their young family with the birth of Fraser B. in 1883. Brother Andrew and sister Elsie followed. David possessed a reticent affect and strong work ethic and was said to be "addicted to apples and weak tea." He practiced for 60 years with the same arduous schedule: office hours from 8 to 11 AM and again from 6 to 9 PM with house calls sandwiched in between. Saturday afternoons and Sundays were taken off. He abhorred tobacco products in any form and strong

\footnotetext{
From the Division of Cardiothoracic Surgery, Fletcher Allen Health Care, Burlington, Vt.

Disclosures: Joseph Schmoker receives honoraria from Medtronic, Inc.

Received for publication Sept 24, 2014; accepted for publication Sept 28, 2014; available ahead of print Oct 22, 2014.

Address for reprints: Joseph Schmoker, MD, Division of Cardiothoracic Surgery, 111 Colchester Ave, MCHV Campus Fletcher 4, Burlington, VT 05401 (E-mail: joseph.schmoker@vtmednet.org).

J Thorac Cardiovasc Surg 2015;149:405-7

$0022-5223 / \$ 36.00$

Copyright (C) 2015 by The American Association for Thoracic Surgery

http://dx.doi.org/10.1016/j.jtcvs.2014.09.108
}

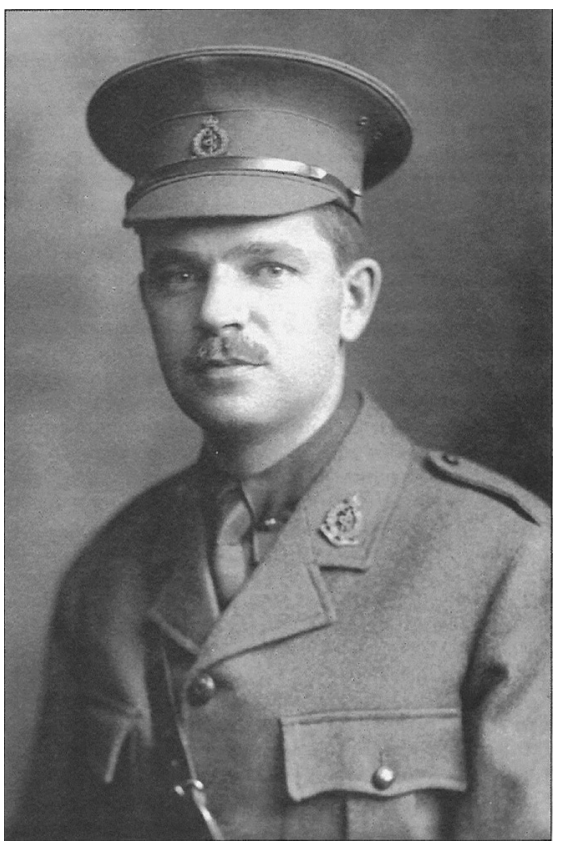

FIGURE 1. Fraser B. Gurd, 1914.

drink, and was an abstainer for his entire life, likely reflecting his family experiences in his formative years. He strongly preached against these vices to his patients and expounded on the benefits of eating an apple every day. David's practice, which encompassed a meaningful proportion from the poorer reaches of Montreal's Victorian society in lowertown, with their attendant class-related maladies as a result of the city's general neglect of sanitation and nutrition for the poor at that time, had a strong influence on Fraser while he was growing up and set his future interests in place.

From all accounts, Fraser was an outgoing and eventempered child with a powerful will. Like his father, he was an outstanding student, beginning his education at the Eglington preparatory school and finishing high school in the early summer of 1900 . He matriculated into the combined 8-year Bachelor of Arts and Medical Degree program at McGill and finished in 6 years. He received the McGill Society Prize at graduation and was ranked ninth in his class, much to the pleasure of his proud father. Fraser and his father were similar in many ways such that "the apple did not fall far from the tree," with their mutual dedication and interest in the study of medicine; however, in other areas it was obvious that the apple fell and rolled down the hill. Although his father was rail-thin in stature and practiced calisthenics with Indian clubs on a daily basis, 
Fraser was portly, avoided competitive sports other than a civilized game of tennis now and then, and was celebrated for his discerning appetite. A quote from his college annual reads, "The tocsin of his soul, the dinner bell." Another vice that escaped his father but plagued Fraser for most of his life, much to his father's chagrin, was his affinity for tobacco products. Fraser did manage to avoid alcohol in his early life until introduced by his daughter-in-law Lulu to the urbane act of partaking in a whiskey sour each night before dinner.

Fraser entered medical school at a time of rapid change in the medical education system occurring both in the United States and Canada. Purely didactic lectures were giving way to the practicality of basic science laboratories and hospital ward instruction. Fraser had at his disposal the vast clinical resources of both the Montreal General Hospital and the newly opened Royal Victoria. He studied from his father's old mentor's text book, the Principles and Practice of Medicine, fifth addition, by William Osler, in which 80 pages were devoted to tuberculosis, which according to Osler was "the most universal scourge of the human race." This chapter received the most attention from Fraser if the degree of highlighting was in any way an indication. The disease, which first captured his attention as a young boy while observing his father treat the underprivileged in their home, continued its hold on his inquiring mind and would do so for the rest of his life.

Fraser was 1 of 8 young men accepted as house surgeons at the Montreal General in 1906 to begin their postgraduate surgical training; they were provided with food, uniforms, and lodging with the expectation that they would live in the hospital at all times, and all with no pay. He was honored after 1 year of work with a training position in pathology, with emphasis on bacteriology, under the guidance of the American transplant Dr Charles W. Duval. During this year, he honed his research and writing skills. He was also responsible for the conduct of autopsies, which at that time numbered approximately 250 per year at Montreal General. Performing autopsies in that era could be a dangerous endeavor if one received a cut during the procedure. A former head of the department died of sepsis after one such event. Fraser did receive a nick to his right middle finger, which became violently inflamed and resulted in symptoms of systemic sepsis. He was saved by a staff surgeon who incised the entire length of the finger but was left with a semiflexed and frozen digit for the rest of his life.

Fraser completed his last 6 months of formal training with the planned study of bacteriology in Germany by traveling to the major centers of the time, as was the custom. He then moved on to a faculty position in pathology at Tulane under Dr Duval, who had recently moved from Montreal to take a Chair position. With the promise of a paying job (\$3000 per year) Fraser proposed to his childhood sweetheart, Jess Newman, who had lived several houses from him while growing up; the age difference between them was just 2 weeks and she died 2 months before him. The 38-year marriage produced 1 child, Fraser N. Gurd, who continued the Gurd tradition of a career as a physician and became a prominent surgeon in his own right.

At Tulane, Fraser B. devoted himself to bacteriology research at the medical school and to surgical pathology at the Touro Infirmary. His research projects included the study of syphilis, influenza, dysentery, leprosy, and the native immune system. He was very productive to the point of being considered a Chair candidate at the age of 27 years, and received several offers from other institutions. However, he was tiring of pathology and began to reminisce fondly of his time in training in surgery. Influenced by the great surgeon Rudolph Matas, who was at Tulane at the time, Fraser decided to switch careers and return to surgery. With Jess pregnant with their first child and not wishing to spend another humid summer in New Orleans, she suggested to Fraser that he seek a position back in Montreal. He received an appointment to the junior staff at Montreal General and an appointment as assistant instructor in surgery. Consistent with his work ethic he also obtained a position in bacteriology to maintain a research laboratory presence, and an appointment at the Western Hospital of Montreal to develop a private practice to better support his family.

With the advent of World War I, Fraser saw an opportunity to serve his country and to gain more surgical experience as he was still a junior surgeon with few credentials, and was yet to be inducted into the Royal College of Surgeons. He was assigned to the No. 22 Casualty Clearing Station in France and was deployed in 1915. True to his nature, in his down time he sought out cultural pursuits such as oil painting, fine cuisine, and even a nearby Canadian unit with a "very credible tennis court and some very attractive nurses who serve tea." But Fraser did get his wish for surgical experience and in a 24-hour period during the battle of Loos saw 500 wounded triaged through the No. 22.

By 1918, the exhaustion of war had set in and he returned to Montreal in June to resume his practice. He was made surgeon-in-chief at St Anne's Military Hospital in 1919, a trip of 30 minutes by train from Montreal. There he encountered chronically infected fractures and draining chest wounds from the war zone. He submitted a paper on 25 patients with chronically draining chest wounds, which was accepted by the American Association for Thoracic Surgery (AATS) for presentation in 1920, the year he was elected to membership. He delivered another paper in Boston at the AATS meeting in 1921 describing scoliosis in association with chronically infected open pneumothorax. This was followed by a lead publication in the American Journal of Surgery in 1922 on thoracic disease. This work generated the invitation to manage all public patients admitted to Montreal General who were in need of major thoracic surgery. In 1924, 
the Western Hospital merged with Montreal General and he was made an associate surgeon. He also began a lifelong relationship with the American College of Surgeons, beginning with service on the fracture committee in 1922 and served through various appointments until he died. He maintained an interest in burns and fracture care throughout his career.

In 1929, Fraser pulled up his family for a sabbatical year in Europe. This was partly a cultural adventure and partly a medical tutorial. With regard to the latter, he observed fracture therapy in Vienna, radiation therapy in Paris and Stockholm, and thoracoplasty for tuberculosis in Berlin under Dr Ferdinand Sauerbruch. From this experience, he brought thoracoplasty to Montreal. As the Montreal General did not admit patients with tuberculosis, he set about organizing a facility to practice his new found knowledge. He became surgeon-in-chief at the Grace Dart Home Hospital for Tuberculosis. There he performed extrapleural thoracoplasty with poor initial results. Surmising that the poor results were due to general anesthesia, he developed a high spinal protocol with sedation and the results improved. He presented this work at the June meeting of the AATS in 1937. During this time, Fraser remained active in local and national Canadian societies and became president of several. He was named president of the AATS in 1940 and gave his presidential address at the June meeting in 1941 on aggressive treatment of pulmonary abscess.

Aside from his clinical work, Gurd worked tirelessly to reorganize the university practice at Montreal General from the entrenched private practice model to an organization of salaried surgeons with teaching and research appointments, supported by a full time surgeon-in-chief. He saw all too clearly in his lifetime how, without the umbrella of a salaried job, scientific inquisitiveness and investigation took second fiddle to a private practice required to support a family. He sought to institute organized graduate training in surgery, establish research facilities within the institution, and increase the number of hospital beds for surgical use. This mission remained an uphill battle for most of his career but came to fruition in 1947 when he was made surgeon-in-chief at Montreal General.

Gurd presented his last paper to the AATS in 1946, a study describing decortication for the treatment of tuberculus empyema, some 50 years after his interest in the disease was inspired by observation of his father's care to the indigent patients with tuberculosis from the tenements that he served from his humble home office. That Fraser B. revolutionized the care of tuberculosis in Montreal is a tribute to both father and son.

Gurd continued to "smoke a full flat fifty" of Gold Flame cigarettes each day and died at the age of 65 years on a train back to Montreal from Chicago after attending a Board of Regents meeting of the Central Surgical Association. He left his mark in the fields of thoracic surgery, trauma surgery, and surgical education, all the while known as "having unfailing politeness to colleagues, patients, and subordinates."

\section{Reference}

1. Gurd FN. The Gurds. The Montreal General and McGill: A Family Saga. Burnstown, Ontario: General Store Publishing House; 1996. 